\title{
Novel approaches to chemical risk assessment.
}

\author{
Henk A Tennekes* \\ Experimental Toxicology Services (ETS) Nederland BV, Frankensteeg 4, 7201KN Zutphen, The Netherlands
}

Accepted on October 27, 2017

The determination of safe levels of exposure to potentially poisonous substances for humans and the environment is a fundamental goal of toxicology. Adverse effects result from interactions of the chemical with critical receptors in the organism, the extent of which depends on the exposure level but often on exposure time as well. Time-dependent toxicity occurs when the receptor binding is either slowly reversible or irreversible, and cumulative effects may also occur under such conditions [1]. However, dose-time-response studies to demonstrate time-cumulative toxicity are rarely conducted.

Traditional toxicity testing usually evaluates effects of three dose levels of a chemical in animal studies under 4-week sub-acute, 13-week sub-chronic or 2-year chronic exposure durations. Adverse effects are expected at high dose, while mid-dose and low-dose level is expected to provide the lowest-observedadverse-effect level (LOAEL) and the NOAEL (no-observed adverse effect level). The proportion of positive responders observed by the end of the exposure period, however, has little predictive value for the wide range of exposures encountered by humans and other organisms in the environment. Furthermore, cumulative toxicity is not immediately apparent, and the mode of action may also remain elusive.

The current approach to toxicity testing was probably secondary to the adoption of the Acceptable Daily Intake (ADI) concept for chemicals in the early 1960s by FAO and WHO. This concept was promoted by French professor René Truhaut [2], and embraced by the chemical industry as a manageable concept for product development. To define the ADI (the permissible daily human exposure for a life time), the NOAEL is usually divided by a safety factor (in most cases 100) to account for differences in sensitivity between experimental animals and humans, and individual variation in sensitivity between humans. The approach disregards the dose-response relationship and yields insufficient information on the mode of action of the chemical.

The only class of compounds where mode of action and cumulative effects have been taken into account in risk assessment are genotoxic and presumed carcinogenic chemicals. The linear non-threshold (LNT) dose-response model for genetic risk assessments was adopted by the Atomic Energy Commission and by the U. S. Environmental Protection Agency for estimates of the cancer risk from radioactive fallout and chemical carcinogenicity [3-6]. In Germany, a very similar approach for carcinogenic risk assessment was proposed by two renowned scientists in the Farbstoffkommission (Dye Committee) of the Deutsche Forschungsgemeinschaft (DFG, German Research Community), pharmacologist Hermann Druckrey and biochemist (and Nobel Prize winner) Adolf Butenandt [7]. Druckrey had reported a groundbreaking study with the carcinogenic dye 4-dimethylaminoazobenzene (also known as "butter yellow") in rats in 1943 [8]. He showed that the carcinogenic action of "butter yellow" was determined by the total dose, and completely independent of the daily dose. The product of daily dose D and exposure time (up to liver cancer manifestation) T was constant across all doses (Haber's Rule):

D. $\mathrm{T}=$ constant

This study demonstrated that harmful effects of a carcinogen were cumulative and that a threshold may not exist. Druckrey's post-war cooperation with the electrophysicist Karl Küpfmüller [9] provided a theoretical explanation for equation (1) with mathematical analyses of the kinetics of receptor binding [10]. They also postulated that if the effect of receptor binding would be irreversible as well, effects would be amplified over time. An opportunity to test this thesis arose when Peter Magee and John Barnes linked the carcinogenicity of dimethylnitrosamine to alkylation of nucleic acids [11]. Nitrosamines seemed perfect model substances as irreversible DNA alkylation results in irreversible mutations. Druckrey investigated the dose-time relationship of diethylnitrosamine in rats and indeed confirmed potentiation of carcinogenicity by exposure time [12] which could be expressed as follows:

D. $\mathrm{T}^{\mathrm{n}}=$ constant

with a value of the time exponent $\mathrm{n}$ of 2.3. This dose-response relationship is now referred to as the Druckrey-Küpfmüller equation.

It was recently demonstrated that equations (1) and (2) are not confined to chemical carcinogenicity but describe the toxicity of non-genotoxic chemicals (neonicotinoid insecticides, cartap, diphacinone, and organic mercury) as well [13-16], and reflect irreversible receptor binding and irreversible effects, with no indications for a threshold [17]. Thus, the ADIs established for these substances underestimate the actual risks.

These new insights indicate the urgent need to establish dosetime-response relationships in toxicity testing, because they identify irreversible effects and cumulative toxicity. In addition, dose-time-response relationships can make accurate estimates of the risks in the real world. This may make risk management more restrictive, but a lot safer.

\section{References}

1. Tennekes HA, Sánchez-Bayo F. Time-Dependent Toxicity of Neonicotinoids and Other Toxicants: Implications for a New Approach to Risk Assessment. J Environment Analytic Toxicol. 2011;S4:001. doi:10.4172/2161-0525.S4-001. 
2. Truhaut R. The concept of the acceptable daily intake: an historical review. Food Addit Contam. 1991; 8:151-62.

3. Anonymous. Genetic effects of atomic radiation. Summary Report of the Committee on Biological Effects of Atomic Radiation by the National Academy of Sciences, BEAR I Genetics Panel (W. Weaver, Chair). Science. 1956;124:170.

4. Albert RE. Carcinogen risk assessment. Environmental Health Perspectives. 1989;81:103-05.

5. Environmental Protection Agency (EPA). Health risk and economic impact assessments of suspected carcinogens. Fed Regist. 1976;41:21402-05.

6. Environmental Protection Agency (EPA). Guidelines for Carcinogen Risk Assessment, EPA/630/P-03/001F, pp. 2005;1-166.

7. Stoff VH. Zur Kritik der Chemisierung und Technisierung der Umwelt. Risiko-und Präventionspolitik von Lebensmittelzusatzstoffen in den 1950er Jahren. Technikgeschichte Bd. 2014;81:253-73.

8. Druckrey H. Quantitative Grundlagen der Krebserzeugung. Klinische Wochenschriften. 1943;22:532-34.

9. Wunderlich V. On the Origins of the Druckrey-Küpfmüller Papers (1948-1949): Dose-Effect Relations in Carcinogenic Substances. Medizinhist J. 2005;40:369-97.

10. Druckrey H, Küpfmüller K. Dosis und Wirkung. Beiträge zur theoretischen Pharmakologie, Editio Cantor GmbH, Freiburg im Breisgau, Germany. 1949.

11. Magee PN, Barnes JM. The production of malignant primary hepatic tumours in the rat by feeding dimethylnitrosamine. Br J Cancer. 1956;10:114-22.

12. Druckrey H, Schildbach A, Schmaehl D, et al. Quantitative Analysis of the Carcinogenic Effect of Diethylnitrosamine. Arzneimittelforschung. 1963;13:841-51.

13. Sánchez-Bayo F. From simple toxicological models to prediction of toxic effects in time. Ecotoxicology. 2009;18:343-54.

14. Tennekes HA. The significance of the Druckrey-Küpfmüller equation for risk assessment-the toxicity of neonicotinoid insecticides to arthropods is reinforced by exposure time. Toxicology. 2010;276:1-4.

15. Tennekes HA, Sánchez-Bayo F. The molecular basis of simple relationships between exposure concentration and toxic effects with time. Toxicology. 2013;309:39-51.

16. Pletz J, Sánchez-Bayo F, Tennekes HA. Dose-response analysis indicating time-dependent neurotoxicity caused by organic and inorganic mercury- Implications for toxic effects in the developing brain. Toxicology. 2016;347$349: 1-5$

17. Tennekes HA. A Critical Appraisal of the Threshold of Toxicity Model for Non-Carcinogens. J Environ Anal Toxicol. 2016;6:5.

\section{*Correspondence to:}

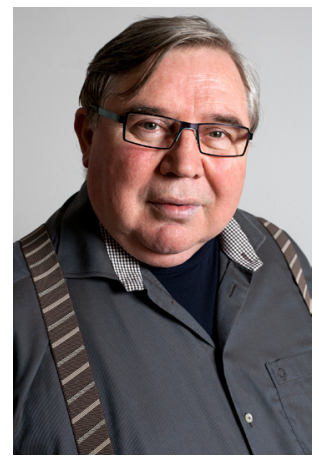

Henk A Tennekes (Editor-in-Chief)

Experimental Toxicology Services (ETS) Nederland BV

The Netherlands

Tel: +31(0)575 547717

E-mail: info@toxicology.nl 